\title{
Serological evidence of hantavirus infection in rural and urban regions in the state of Amazonas, Brazil
}

\author{
João Bosco Lima Gimaque ${ }^{1,2} /+$, Michele de Souza Bastos ${ }^{1,2}$, \\ Wornei Silva Miranda Braga ${ }^{1,2}$, Cintia Mara Costa de Oliveira ${ }^{1,2}$, Márcia da Costa Castilho, ${ }^{1,2}$, \\ Regina Maria Pinto de Figueiredo', Elizabeth dos Santos Galusso ${ }^{3}$, Evaulino Ferreira Itapirema ${ }^{4}$, \\ Luiz Tadeu Moraes de Figueiredo ${ }^{5}$, Maria Paula Gomes Mourão ${ }^{1,2}$
}

\author{
${ }^{1}$ Fundação de Medicina Tropical Dr. Heitor Vieira Dourado, Manaus, AM, Brasil ${ }^{2}$ Universidade do Estado do Amazonas, \\ Manaus, AM, Brasil ${ }^{3}$ Universidade do Norte, Manaus, AM, Brasil ${ }^{4}$ Universidade Paulista, Manaus, AM, Brasil \\ ${ }^{5}$ Faculdade de Medicina de Ribeirão Preto, Universidade de São Paulo, Ribeirão Preto, SP, Brasil
}

\begin{abstract}
Hantavirus disease is caused by the hantavirus, which is an RNA virus belonging to the family Bunyaviridae. Hantavirus disease is an anthropozoonotic infection transmitted through the inhalation of aerosols from the excreta of hantavirus-infected rodents. In the county of Itacoatiara in the state of Amazonas (AM), Brazil, the first human cases of hantavirus pulmonary and cardiovascular syndrome were described in July 2004. These first cases were followed by two fatal cases, one in the municipality of Maués in 2005 and another in Itacoatiara in 2007. In this study, we investigated the antibody levels to hantavirus in a population of 1,731 individuals from four different counties of AM. Sera were tested by IgG/IgM-enzyme-linked immune-sorbent assay using a recombinant nucleocapsid protein of the Araraquara hantavirus as an antigen. Ten sera were IgG positive to hantavirus (0.6\%). Among the positive sera, $0.8 \%$ (1/122), $0.4 \%$ (1/256), $0.2 \%$ (1/556) and $0.9 \%$ (7/797) were from Atalaia do Norte, Careiro Castanho, Itacoatiara and Lábrea, respectively. None of the sera in this survey were IgM-positive. Because these counties are distributed in different areas of AM, we can assume that infected individuals are found throughout the entire state, which suggests that hantavirus disease could be a local emerging health problem.
\end{abstract}

Key words: hantavirus - IgG antibodies to hantavirus - western Brazilian Amazon

Hantaviruses are spherical, enveloped RNA viruses, measuring $80-120 \mathrm{~nm}$. The viral RNA is single-stranded and forms three segments with negative polarity. The RNA segments are named large (L), medium (M) and small (S). The L, M and S segments encode the RNAdependent RNA polymerase, the envelope glycoproteins and the viral nucleocapsid $(\mathrm{N})$ protein, respectively (Plyusnin et al. 1996). Rodents and insectivores are hantavirus reservoirs and specific virus species are typically associated with specific rodents; thus, each hantavirus is limited to one geographic region, according to the habitat of the rodent reservoir (Plyusnin 2002, Zhang et al. 2010).

Human infection by hantavirus occurs most often by the inhalation of aerosols from the excretions of contaminated rodents. However, another form of hantavirus transmission of great epidemiological importance, from human to human, has been described on the American continent, especially in Argentina and Chile (Cantoni et al. 1997, Zhang et al. 2010). Between 1993-2010, more than 1,300 cases of HPCS have been reported in all the Brazilian regions, distributed throughout 14 states (MS/ SVS/DVE 2010). Five hantaviruses have been reported to

Financial support: FAPEAM, CNPq, CAPES, SUFRAMA

+ Corresponding author: gimaque@ig.com.br

Received 18 March 2011

Accepted 25 November 2011 cause hantavirus pulmonary and cardiovascular syndrome (HPCS) in Brazilian patients: Anajatuba, Araraquara, Castelo dos Sonhos, Juquitiba and Laguna Negra-like (Figueiredo et al. 2010). Hantavirus infection in Brazil is predominantly related to agricultural activity and a common manner of contracting this infection, especially in remote small towns, is through the cleaning of rural grain storage buildings. Other forms of infection occur through direct contact with infected rodents or leisure activities, such as fishing, hunting or camping (MS/SVS 2005).

Most of the HPCS cases have occurred in the southern and southeastern regions, whereas the northern region contributed $6.36 \%$ of the total reported cases. Among the northern cases, 73 cases were from the state of Pará (PA), three cases were from the state of Acre and only four cases were reported in the state of Amazonas (AM) (MS/SVS 2006, MS/SVS/DVE 2010). In the county of Itacoatiara (lower Amazon River), in July 2004, the first human cases of infection by hantavirus in AM were identified. Three farmers from the same family that lived in a rural area had fevers and two of them developed acute HCPS. One of the farmers from that outbreak passed away. In 2005, another case of fatal HCPS was identified in the county of Maués and another was identified in July 2007 in Itacoatiara (Gattás et al. 2004, MS/SVS 2004, Santos et al. 2006).

Considering that hantavirus infection is a serious and potentially emerging disease, a pilot serological survey of hantavirus was performed in a population sample of four counties from three regions in AM, from 2007-2009. Sera samples were obtained from 1,731 participants aged two- 
89 years [926 females (53.5\%) and 805 males (46.5\%)] living in four counties of AM: Itacoatiara $\left(3^{\circ} 08^{\prime} 24.24\right.$ 'S $58^{\circ} 26^{\prime} 19.67^{\prime}$ 'W), Lábrea (7¹5'38.60”'S 6447'52.83”W), Careiro Castanho ( $\left.3^{\circ} 48^{\prime} 43.64^{\prime \prime} \mathrm{S} 60^{\circ} 20^{\prime} 44.00^{\prime \prime} \mathrm{W}\right)$ and Atalaia do Norte $\left(4^{\circ} 22^{\prime} 22.83^{\prime \prime} \mathrm{S} 70^{\circ} 11^{\prime} 33.27^{\prime \prime} \mathrm{W}\right)$. These four counties are located in the southwestern, southern and eastern regions of AM, as shown in Figure. The participants were living either in rural areas $(53.1 \%)$ or in urban areas $(46.9 \%)$, as shown in Table I.

All of the sera analysed in the study were part of the serum bank of the Virology Laboratory of the Foundation for Tropical Medicine Dr Heitor Vieira Dourado (FMTHVD). The study was approved by the Ethical Committee for Human Research of FMT-HVD and complies with the 196/96 resolution of the National Health Council. All of the study participants gave informed consent and authorised the storage of their sera for virus survey studies. The procedures for this study were performed in the Virology Laboratory of FMT-HVD. Sera were tested for specific IgM and IgG antibodies by an enzyme-linked immune-sorbent assay (ELISA) using a recombinant $\mathrm{N}$ protein of the Araraquara hantavirus as an antigen, as described elsewhere (Figueiredo et al. 2008, 2009). Briefly, 96 -well microplates were coated with a recombinant $\mathrm{N}$ protein of the Araraquara virus (wells: A-D - 1-12) and a negative antigen extract (Escherichia coli; wells: E-H - 1-12), which were both diluted in $\mathrm{pH} 9.6$ phosphate buffered saline (PBS) buffer. The plates were incubated overnight at $4^{\circ} \mathrm{C}$ in a moist chamber. On the next day, the microplate wells were washed five times with $0.05 \%$ Tween-20 in pH 7.4 PBS (PBS-T). In 10\% skimmed milk solution in PBS was added to the wells, incubated for 1 $\mathrm{h}$ and washed six times. The microplates were incubated in humid chambers for $2 \mathrm{~h}$ at $37^{\circ} \mathrm{C}$ and washed five times with PBS-T. The testing sera were added to corresponding wells at a 1:100 dilution in both parts of the plate, including a positive IgG sera (positive control) and a pool of negative IgG sera (negative control), both in triplicate. After $1 \mathrm{~h}$ of incubation at $37^{\circ} \mathrm{C}$ in a humid chamber, the plates were washed six times with PBS-T. An immunoglobulin conjugate (goat anti-human IgG peroxidase), which was diluted 1:2000 in PBS-lamellipodin, was added to the wells, incubated for $1 \mathrm{~h}$ and washed six times. Subsequently, ABTS substrate was added to the wells and incubated for $15-20 \mathrm{~min}$ at $37^{\circ} \mathrm{C}$ in a humid chamber for coloured development. The reaction was blocked with $1 \mathrm{M} \mathrm{HCl}$ solution and the absorbance [optical density (OD)] was read in a spectrophotometer at $405 \mathrm{~nm}$. After subtracting the OD values of the wells that were coated with the negative extract from those that were coated with the $\mathrm{N}$ protein of Araraquara virus, the cut-off point for determining the positive sera at each serum dilution was determined as the mean of the optical densities of the triplicate negative control sera plus three standard deviations. The same procedures were performed for IgM detection, using positive human controls with HCPS and goat anti-human IgM peroxidase.

Ten sera had $\operatorname{IgG}$ antibodies to hantavirus $(0.6 \%$ positivity). IgG-titres to hantavirus of 1:1600 and 1:400 were observed in one serum each and eight sera had a 1:100 titre.

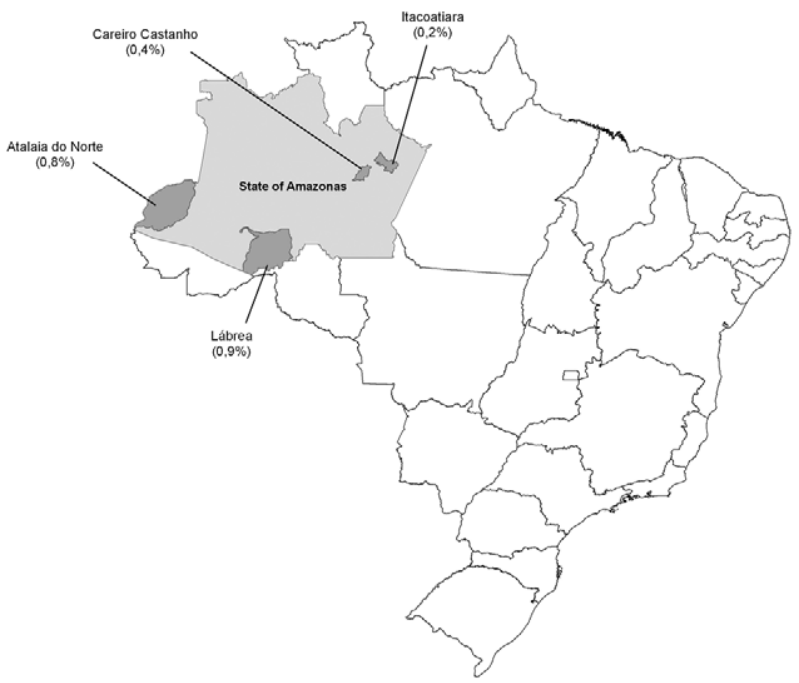

Map of Brazil highlighting the state of Amazonas, the municipalities of the study area and the percentage of IgG hantavirus-positive cases.

Among the seropositive participants, $0.8 \%(1 / 122)$ was from Atalaia do Norte, $0.4 \%$ (1/256) from Careiro Castanho, $0.2 \%(1 / 556)$ from Itacoatiara and $0.9 \%$ (7/797) from Lábrea, as shown in Table II. Higher positivity rates, although not statistically significantly $(\mathrm{p}$ $=0.38$ ), were observed in the counties of Lábrea and Atalaia do Norte. The rate of serum positivity was 3.5 times higher in participants residing in rural areas compared to those residing in urban areas $(95 \%$, confidence interval $0.7-10$ ), although it was not statistically significant ( $\mathrm{p}$ $=0.07$ ). Notably, all 10 individuals who were serologically positive for hantavirus had contact with the forest.

There was no detected seropositivity for IgM in all of the 1,731 subjects enrolled in the study.

The IgG-ELISA using a recombinant $\mathrm{N}$ protein of the Araraquara hantavirus was simple to perform and has proved suitable for serological surveys, which corroborates the data from previous studies (Figueiredo et al. 2008, 2009).

It was observed that $0.6 \%$ of the sera from the participants of all four counties, which are located in different regions of AM, had IgG antibodies to hantavirus. In the Americas, a seroprevalence of $2.15 \%$ of the IgG antibodies to hantavirus has been reported among the residents of three towns in the Chilean Andean region (Frey et al. 2003), whereas in Panama, the seroprevalence was high in children under 11 years old $(9.2 \%)$ and reached $22.8 \%$ in adults aged 41-50 years old (Armien et al. 2004). In Brazil, in the state of São Paulo, a study performed in the counties of Ribeirão Preto, Guariba and Jardinópolis found $1.23 \%$ seropositivity to hantavirus (Holmes et al. 2000). In northern Brazil, in the counties of Novo Progresso and Trairão, PA, the seroprevalence to hantavirus was $2.16 \%$ and $4.37 \%$, respectively (Medeiros et al. 2010). The low seroprevalence to hantavirus observed in the present study could be associated with the low agricultural activity in AM. The highest seropositivity, $0.9 \%$, was observed in Lábrea, where agricultural activity and livestock are more intense. 
TABLE I

Information on the county of origin, area of residence, year of blood collection and number of samples

\begin{tabular}{lccc}
\hline County & $\begin{array}{c}\text { Samples } \\
\text { (n) }\end{array}$ & $\begin{array}{c}\text { Area of } \\
\text { residence }\end{array}$ & $\begin{array}{c}\text { Year of } \\
\text { blood collection }\end{array}$ \\
\hline Atalaia do Norte & 122 & Rural & 2008 \\
Careiro Castanho & 256 & Urban & 2009 \\
Itacoatiara & 556 & Urban & 2009 \\
Lábrea & 797 & Rural & 2007 \\
\hline
\end{tabular}

TABLE II

IgG seropositivity to hantavirus by participant gender, age range and area of residence

\begin{tabular}{lcc}
\hline & $\begin{array}{c}\text { Seropositives/ } \\
\text { total } \\
\text { participants }\end{array}$ & $\begin{array}{c}\text { Seropositivity } \\
\text { to hantavirus } \\
(\%)\end{array}$ \\
\hline Male & $5 / 10$ & 50 \\
Female & $5 / 10$ & 50 \\
Rural area & $8 / 10$ & 80 \\
Urban area & $2 / 10$ & 20 \\
5-15 years & $2 / 10$ & 20 \\
16-30 years & $4 / 10$ & 40 \\
31-60 years & $4 / 10$ & 40 \\
\hline
\end{tabular}

A significant difference in seropositivity to hantavirus was not observed between men and women or among distinct age ranges of the study participants, although it was higher among those 16-60 years old. Residents of rural areas had a three times greater risk of hantavirus infection than those of urban areas.

In short, this study confirms preliminary information concerning the occurrence of HCPS cases in AM. In the present study, infected individuals were found in three different regions of AM, which suggests that hantavirus disease could be a local emerging health problem. Further studies in AM are necessary to identify other human infections as well as hantavirus species and rodent-reservoirs.

\section{ACKNOWLEDGEMENTS}

To Dr Rajendranath Ramasawmy, for his peer review of this paper.

\section{REFERENCES}

Armien B, Pascale JM, Bayard V, Munoz C, Mosca I, Guerrero G, Armien A, Quiroz E, Castillo Z, Zaldivar Y, Gracia F, Hjelle B, Koster F 2004. High seroprevalence of hantavirus infection on the Azuero Peninsula of Panama. Am J Trop Med Hyg 70: 682-687.
Cantoni G, Lázaro M, Resa A, Arellano O, Amestoy AM, De Bunder S, Herrero E, Perez A, Larrieu E 1997. Hantavirus pulmonary syndrome in the province of Rio Negro, Argentina, 1993-1996. Rev Inst Med Trop Sao Paulo 39: 191-196.

Figueiredo GG, Borges AA, Campos GM, Machado AM, Saggioro FP, Sabino GS, Badra SJ, Ortiz AAA, Figueiredo LTM 2010. Diagnosis of hantavirus infection in humans and rodents in Ribeirão Preto, state of São Paulo, Brazil. Rev Soc Bras Med Trop 43: 348-354.

Figueiredo LTM, Moreli ML, Borges AA, Figueiredo GG, Badra SJ, Bisordi I, Suzuki A, Caprina S, Padula P 2009. Evaluation of an enzyme-linked immunosorbent assay based on Araraquara virus recombinant nucleocapsid protein. Am J Trop Med Hyg 81: 273-276.

Figueiredo LTM, Moreli ML, Borges AA, Figueiredo GG, Souza RLM, Aquino VH 2008. Expression of a hantavirus N protein and its efficacy as antigen in immune assays. Braz J Med Biol Res 41: 596-599.

Frey MT, Vial PC, Castillo CH, Godoy PM, Hjelle B, Ferrés MG 2003. Hantavirus prevalence in the IX region of Chile. Emerg Infect Dis 9: 827-832.

Gattás VL, Siqueira A, Lima Neto AS, Mourão MPG, Oliveira WK, Carmo EH 2004. Sistema de vigilância de síndrome febril ictérica aguda e/ou síndrome febril hemorrágica aguda. Brasil. Boletim Eletrônico Epidemiológico 4: 1-5.

Holmes et al. 2000. Holmes R, Boccanera R, Figueiredo LTM, Mançano SR, Pane C 2000. Seroprevalence of human hantavirus infection in the Ribeirão Preto region of São Paulo state, Brazil. Emerg Infect Dis 6: 560-561.

Medeiros DBA, da Rosa EST, Marques AAR, Simith DB, Carneiro AR, Chiang JO, Prazeres ITE, Vasconcelos PFC, Nunes MRT 2010. Circulation of hantaviruses in the influence area of the Cuiabá-Santarém Highway. Mem Inst Oswaldo Cruz 105: 665-671.

MS/SVS - Ministério da Saúde/Secretaria de Vigilância em Saúde Brasil 2004. Investigation report on hantavirus cardiopulmonary syndrome cases at Itacoatiara municipality, Amazonas state. Available from: bvsms.saude.gov.br/bvs/publicacoes/guia_bolso_4ed.pdf

MS/SVS - Ministério da Saúde/Secretaria de Vigilância em Saúde Brasil 2005. Guia de vigilância epidemiológica. Available from: bvsms.saude.gov.br/bvs/publicacoes/Guia_Vig_Epid_novo2.pdf.

MS/SVS - Ministério da Saúde/Secretaria de Vigilância em Saúde Brasil 2006. Epidemiologia da hantavirose e da síndrome cardiopulmonar por hantavírus no Brasil no ano de 2005. Boletim Eletrônico Epidemiológico 5:1-5.

MS/SVS/DVE - Ministério da Saúde/Secretaria de Vigilância em Saúde/Departamento de Vigilância Epidemiológica Brasil 2010. Casos e óbitos por hantavirose por unidade federada provável de infecção e ano, 1993-2010. Available from: portal.saude.gov.br/ portal/arquivos/pdf/casos_obitos_hantaan_uf_ano_2010.pdf.

Plyusnin A 2002. Genetics of hantaviruses: implications to taxonomy. Arch Virol 147: 665-682.

Plyusnin A, Vapalahti O, Vaheri A 1996. Hantaviruses: genome structure, expression and evolution. J Gen Virol 77: 2677-2687.

Santos MC, Lacerda MV, Benedetti SM, Albuquerque BC, Aguiar Filho AA, Rosa Elkhoury M, Travassos da Rosa ES, Vasconcelos PF, Medeiros DB, Mourão MP 2006. Human hantavirus infection, Brazilian Amazon. Emerg Infect Dis 12: 1165-1167.

Zhang YZ, Lin XD, Shi Nf, Wang W, Liao Xw, Guo WP, Fan FN, Huang XM, Li MH, Li MF, Chen Y, Chen XF, Fu ZF, Plyusnin A 2010. Hantaviruses in small mammals and humans in the coastal region of Zhejiang province, China. J Med Virol 82: 987-995. 